\title{
Drug Development, Experimental
}

National Cancer Institute

\section{Source}

National Cancer Institute. Drug Development, Experimental. NCI Thesaurus. Code C15982.

Drug development activites focused on the phases preceding preclinical trials and testing. 